\title{
Flavonoid Derivatives from the Aerial Parts of Trifolium trichocephalum M. Bieb. and Their Antioxidant and Cytotoxic Activity
}

\section{Gülin Renda $^{1^{*}}$, Ufuk Özgen ${ }^{1}, Z_{\text {Zeynep Ünal }}{ }^{2}$, Suna Sabuncuoğlu ${ }^{2}$, Erhan Palaska $^{3}$ and İlkay Erdoğan Orhan ${ }^{4}$}

\author{
${ }^{1}$ Karadeniz Technical University, Faculty of Pharmacy, Department of Pharmacognosy, Trabzon, Türkiye \\ ${ }^{2}$ Hacettepe University, Faculty of Pharmacy, Department of Toxicology, Ankara, Türkiye \\ ${ }^{3}$ Hacettepe University, Faculty of Pharmacy, Department of Pharmaceutical Chemistry, Ankara, Türkiye \\ ${ }^{4}$ Gazi University, Faculty of Pharmacy, Department of Pharmacognosy, Ankara, Türkiye
}

(Received March 15, 2017; Revised May 22, 2017; Accepted May 24, 2017)

\begin{abstract}
Trifolium L. species with a rich isoflavone content have been used as expectorant, analgesic, antiseptic, tonic, and wound-healer in folk medicine. The aim of the study is to evaluate pharmacological properties of the extracts and isolated compounds of $T$. tricocephalum. Phytochemical investigation of the aerial parts of $T$. trichocephalum led to the isolation of daidzein, genistein, quercetin, and daidzein 4 '- $O$ - $\beta$-glucoside for the first time from this species. Isolated compounds along with the methanol extract, water, ethyl acetate and chloroform subextracts were tested for their radical scavenging and cytotoxic activity which was evaluated by MTT assay. According to the results of activity tests, extracts showed a concentration-dependent radical scavenging activity as well as cytotoxic effect on HepG2 cells at $400 \mu \mathrm{g} / \mathrm{mL}$, whereas the compounds did not exert any obvious cytotoxic effect at tested concentrations.
\end{abstract}

Keywords: Antioxidant activity; cytotoxicity; Fabaceae; isoflavonoids; Trifolium trichocephalum. (C) 2017 ACG Publications. All rights reserved.

\section{Plant Source}

The genus Trifolium L. (Fabaceae) is represented by 300 species around the world and 103 species in Turkish flora [1]. The aerial parts of T. trichocephalum were collected from İkizdere town (Rize Province, Turkey) in June, 2011 and identified by one of authors; Dr. Gülin Renda. A voucher specimen (coded as HUEF 09335) was deposited at the Herbarium of Faculty of Pharmacy, Hacettepe University (Ankara, Turkey).

\section{Previous Studies}

In Turkish folk medicine, Trifolium species have been recorded to be used as expectorant, antiseptic, wound-healer, sedative, anticancer, antidiabetic and for the treatment of rheumatism pain,

\footnotetext{
* Corresponding author: E- Mail: grenda@ktu.edu.tr

The article was published by ACG Publications 
menopausal or premenstrual symptoms [2-4]. Over ground parts of some Trifolium species are consumed as snack [5]. Trifolium species are also forage crops that have economic value; especially Trifolium pratense L. is largely cultivated [6]. Up to date, many phytochemical investigations were performed on Trifolium species from which mainly isoflavonoids, saponins, flavonoids, and megastigmane glycosides have been isolated [4, 7-11]. Trifolium species, known as clover, have been patented as commercially available extracts on the market all over the world [4].

Trifolium trichocephalum M. Bieb. is a perennial species growing at eastern regions of Turkey [1]. Luteolin 3'-O-D-glucoside, luteolin 7-O-D-glucoside, and luteolin were reported to be isolated from $T$. trichocephalum previously [12]. Since chemical content of plant species grown in different geographic locations may show variability, phytochemical properties of $T$. trichocephalum have been decided to be re-investigated in the current study. This is the first study that reports some pharmacological properties of the extracts and isolated compounds of T. tricocephalum.

\section{Present Study}

The dried aerial parts of T. trichocephalum $(260 \mathrm{~g})$ were extracted with methanol $(\mathrm{MeOH}, 1500$ $\mathrm{mL} \times 4)$ at $40^{\circ} \mathrm{C}$. The $\mathrm{MeOH}$ extract $(51.0 \mathrm{~g})$ was dissolved in $\mathrm{H}_{2} \mathrm{O}-\mathrm{MeOH}$ (9:1) mixture and partitioned with chloroform and then ethyl acetate, which were concentrated under reduced pressure to give the sub-extracts (10.4 and $3.2 \mathrm{~g}$, respectively). The remaining aqueous sub-extract was $36.2 \mathrm{~g}$.

$0.9 \mathrm{~g}$ of ethyl acetate sub-extract was subjected to a gel chromatography (Sephadex LH-20) column and eluted with $\mathrm{MeOH} ; 17$ fractions were collected. Fraction $4(25 \mathrm{mg})$ gave compound $1(20 \mathrm{mg})$. The fractions 5-17 $(0.8 \mathrm{~g})$ were combined and further applied to silica gel column chromatography using $\mathrm{CHCl}_{3}: \mathrm{MeOH}: \mathrm{H}_{2} \mathrm{O}$ (80:20:2; 70:30:3) solvent system. The sub-fractions 3-4 (0.2 g) of silica gel column chromatography were combined and subjected to gel chromatography (Sephadex LH-20) eluting with $\mathrm{MeOH}$ and preparative TLC, respectively, that yielded compound $2(22 \mathrm{mg})$. The sub-fractions 5-7 $(0.19 \mathrm{~g})$ eluted from silica gel column were also combined and purified by gel chromatography (Sephadex LH-20) eluting with $\mathrm{MeOH}$ to give compound $3(30 \mathrm{mg}) .32 \mathrm{~g}$ of aqueous sub-extract was subjected to reversed phase silica gel column chromatography using $0-100 \%$ aqueous $\mathrm{MeOH}$ as solvent systems. Fraction 9 gave compound $4(25 \mathrm{mg})$.

Compound 1: ${ }^{1} \mathrm{H}$ NMR (200 MHz, $\left.\mathrm{CD}_{3} \mathrm{OD}\right) \delta: 8.28(1 \mathrm{H}, \mathrm{H}-2, \mathrm{~s}), 7.95(1 \mathrm{H}, \mathrm{H}-5, \mathrm{~d}, J=9.0 \mathrm{~Hz}), 7.36$ $(2 \mathrm{H}, \mathrm{H}-2 ', 6 ', \mathrm{~d}, J=8.2 \mathrm{~Hz}), 6.91(1 \mathrm{H}, \mathrm{H}-6, \mathrm{~d}, J=8.6 \mathrm{~Hz}), 6.85(1 \mathrm{H}, \mathrm{H}-8, \mathrm{~s}), 6.79\left(2 \mathrm{H}, \mathrm{H}-3^{\prime}, 5 ', \mathrm{~d}, J=8.6\right.$ $\mathrm{Hz}) ;{ }^{13} \mathrm{C}$ NMR (50 MHz, CD $\left.{ }_{3} \mathrm{OD}\right) \delta: 176.2$ (C-4), 164.0 (C-7), 158.9 (C-9), 158.7 (C-4'), 154.4 (C-2), 131.6 (x2C) (C-2',6'), 128.8 (C-5), 125.0 (C-1'), 124.0 (C-3), 118.1 (C-10), 116.6 (C-6), 116.4 (x2C) (C$\left.3^{\prime}, 5^{\prime}\right)$. Data agree with the data given in the literature for daidzein [13] (Figure 1).

Compound 2: ${ }^{1} \mathrm{H}$ NMR (200 MHz, $\left.\mathrm{CD}_{3} \mathrm{OD}\right): \delta 8.10$ (1H, H-2, s), $7.38\left(2 \mathrm{H}, \mathrm{H}-2^{\prime}, 66^{\prime}, \mathrm{d}, J=8.2 \mathrm{~Hz}\right), 6.86$ $(2 \mathrm{H}, \mathrm{H}-3$ ', 5 ', d, $J=8.2 \mathrm{~Hz}), 6.34$ (1H, H-8, s), 6.22 (1H, H-6, s); ${ }^{13} \mathrm{C}$ NMR $\left(50 \mathrm{MHz}, \mathrm{CD}_{3} \mathrm{OD}\right): \delta 179.4$ (C-4), 169.2 (C-7), 161.0 (C-5), 156.9 (C-9), 156.0 (C-4'), 152.0 (C-2), 128.6 (x2C) (C-2',6'), 121.9 (C3), 120.5 (C-1'), 113.4 (x2C) (C-3', 5'), 101.3 (C-10), 97.3 (C-6), 92.0 (C-8). ${ }^{1} \mathrm{H}$ NMR and ${ }^{13} \mathrm{C}$ NMR data agree with the data given in the literature for genistein $[13,14]$ (Figure 1).

Compound 3: $\mathrm{C}_{15} \mathrm{H}_{10} \mathrm{O}_{7}$ (mol. wt. 302); ESI-MS: m/z: 303.04 [M+H] ${ }^{+} ;{ }^{1} \mathrm{H}$ NMR (600 MHz, DMSO-d6) $\delta: 7.61(1 \mathrm{H}, \mathrm{H}-2$ ', d, $J=2.4 \mathrm{~Hz}), 7.50(1 \mathrm{H}, \mathrm{H}-6$ ', dd, $J=2.4,8.8 \mathrm{~Hz}), 6.85(1 \mathrm{H}, \mathrm{H}-5$ ', d, $J=8.8 \mathrm{~Hz}), 6.38$ $(1 \mathrm{H}, \mathrm{H}-8, \mathrm{~d}, J=1.8 \mathrm{~Hz}), 6.15(1 \mathrm{H}, \mathrm{H}-6, \mathrm{~d}, J=2.3 \mathrm{~Hz}) ;{ }^{13} \mathrm{C}$ NMR $\left(125 \mathrm{MHz}, \mathrm{DMSO} \mathrm{d}_{6}\right): \delta 176.2(\mathrm{C}-4)$, 164.3 (C-7), 161.1 (C-5), 156.6 (C-9), 148.1 (C-4'), 147.2 (C-2), 145.5 (C-3'), 136.1 (C-3), 122.4 (C-1'), 120,5 (C-6'), 116.0 (C-5'), 115.4 (C-2'), 103.4 (C-10), 98.6 (C-6), 93.8 (C-8) ${ }^{1} \mathrm{H}$ NMR and ${ }^{13} \mathrm{C}$ NMR data agree with the data given in the literature for quercetin [15] (Figure 1).

Compound 4: ${ }^{1} \mathrm{H}$ NMR (600 MHz, DMSO-d6): $\delta 8.38$ (1H, H-2, s), 8.04 (1H, H-5, d), 7.40 (2H, H-2',6', d), $7.22(1 \mathrm{H}, \mathrm{H}-8, \mathrm{~s}), 7.14(1 \mathrm{H}, \mathrm{H}-6, \mathrm{~d}), 6.81\left(2 \mathrm{H}, \mathrm{H}-33^{\prime}, 5^{\prime}, \mathrm{d}\right), 5.11(1 \mathrm{H}, \mathrm{H}-1 "$, d), 3.68-3.18 (6H, m, sugar protons); ${ }^{13} \mathrm{C}$ NMR (125 MHz, DMSO-d6): $\delta 180.3$ (C-4), 166.8 (C-7), 162.7 (C-9), 162.5 (C-4'), 
158.3 (C-2), 135.6 (x2C) (C-2',6'), 132.4 (C-5), 129.1 (C-1'), 127.7 (C-3), 123.9 (C-10), 121.1 (C-6), 120.4 (x2C) (C-3', 5'), 108.8 (C-8), 105.3 (C-1"), 82.6 (C-5"), 81.8 (C-2"), 78.5 (C-3"), 75.0 (C-4"), 66.0 (C-6"). Data agree with the literature for daidzein 4'- $O-\beta$-glucoside [16] (Figure 1).

The correlation between phenolic compounds and strong antioxidant activity has been showed with many studies up to date [17]. Also it has been known that isoflavonoids show antioxidant activity and some of the beneficial effects of them are reported to be connected with this activity [18]. By this point of view, the ethyl -acetate and water subextracts of the $\mathrm{MeOH}$ extract were separated using chromatographic methods to obtain four compounds in total. The structures of the isolated compounds, elucidated by ${ }^{1} \mathrm{H}$ and ${ }^{13} \mathrm{C}$ NMR experiments, were identified as daidzein, genistein, quercetin, and daidzein 4'-O-D-glucoside by comparison of their spectroscopic data (UV, 1D- and 2D-NMR, and MS) with previously published data [13-16].<smiles>[R3]c1ccc(-c2coc3cc(O)cc([R5])c3c2=O)cc1</smiles>

1 Daidzein

2 Genistein

$\mathrm{R}_{5}=\mathrm{H} \mathrm{R}_{4}=\mathrm{OH}$

Daidzein 4'- $O$ - $\beta$-glucoside
$\mathrm{R}_{5}=\mathrm{R}_{4}=\mathrm{OH}$

$\mathrm{R}_{5}=\mathrm{H} \mathrm{R}_{4}=-O-\beta$-glucoside<smiles>O=c1c(O)c(-c2ccc(O)c(O)c2)oc2cc(O)cc(O)c12</smiles>

3

Quercetin

Figure 1. The isolated compounds 1-4.

Furthermore, the radical scavenging effect and cytotoxicity of the methanol extract and water, ethyl acetate, and chloroform subextracts of T. trichocephalum as well as four compounds isolated from this plant were examined.

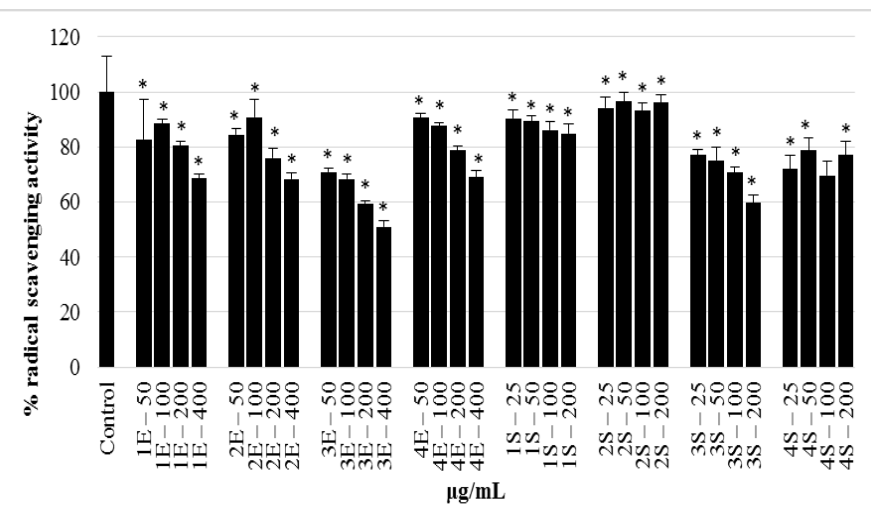

Figure 2. DPPH radical scavenging activity of the extracts and compounds.

1E: $\mathrm{MeOH}$ extract, 2E: $\mathrm{H}_{2} \mathrm{O}$ subextract, 3E: EtOAc subextract, 4E: $\mathrm{CHCl}_{3}$ subextract, 1S: Quercetin, 2S: Daidzein-4'-O- $\beta$-glucoside, 3S: Genistein, $4 \mathrm{~S}$ : Daidzein.* significantly different from control $(\mathrm{p}<0.05)$. Results are expressed as mean $\pm \mathrm{SD}$ values of three observations.

DPPH radical scavenging effect: DPPH radical scavenging effect of the extracts and compounds was assessed through the decolorization of the DPPH solution [19]. The samples at various concentrations (50,100, 200, and $400 \mu \mathrm{g} / \mathrm{mL}$ for extracts; $25,50,100$ and $200 \mu \mathrm{g} / \mathrm{mL}$ for the compounds) were added to DPPH solution. After incubating the remaining DPPH was determined by spectrophotometry at 517 $\mathrm{nm}$. The radical scavenging activity of each sample was expressed as $\% \pm$ standard deviation (SD) compared to blank. The experiment was conducted as triplicate. 
$\mathrm{SO}_{2}{ }^{-}$radical scavenging effect by alkaline DMSO method: The method of Kunchandy and Rao [20] was used for the detection of $\mathrm{SO}_{2}$-scavenging activity of the extract with slight modification [21]. The absorbance was measured at $560 \mathrm{~nm}$ using microplate reader (Spectramax). The radical scavenging activity was given as $\%$ activity $\pm \mathrm{SD}$ compared to blank. The experiment was conducted as duplicate.

NO scavenging effect: Nitric oxide (NO) radical scavenging activity of extracts was determined by the method of Tsai et al. [22]. The absorbance was measured at $577 \mathrm{~nm}$. The radical scavenging activity of each sample was expressed as $\% \pm$ SD compare to blank.

MTT assay for cytotoxicity: Cell viability was evaluated by the reduction of MTT [23, 24]. Briefly, HepG2 cells (10000 cells/well) were treated with the samples at various concentrations $(50,100,200$ and $400 \mu \mathrm{g} / \mathrm{mL}$ for extracts; 25, 50, 100 and $200 \mu \mathrm{g} / \mathrm{mL}$ for compounds). After the incubation with MTT solution, the cells were lysed in DMSO and the MTT formosan was qualified by determining the absorbance at $570 \mathrm{~nm}$. Cell viability was expressed as a percent of the control culture value.

Statistical analysis: The results obtained in vitro were statistically processed using Microsoft Excel program. Student's $t$-test was applied and $\mathrm{p}<0.05$ was accepted for statistical significance.

All tested extracts possessed a potent DPPH radical scavenging effect and the maximum effect was observed at $400 \mu \mathrm{g} / \mathrm{mL}$ concentration for each extract. Water extract exhibited $90.84 \%$ scavenging effect on DPPH radical at the concentration of $100 \mu \mathrm{g} / \mathrm{mL}$. All compounds exhibited scavenging effect, among which daidzein 4 '- $O-\beta$-glucoside was the most active one with the inhibition ratio of $96.48 \%$ at the concentration of $50 \mu \mathrm{g} / \mathrm{mL}$.

According to the results obtained from the SO method as seen in Figure. 3, all of the samples showed significant activity. Ethyl acetate subextract and daidzein exhibited the best activity with inhibition ratio of $202.43 \%(50 \mu \mathrm{g} / \mathrm{mL})$ and $100.49 \%(200 \mu \mathrm{g} / \mathrm{mL})$, respectively.

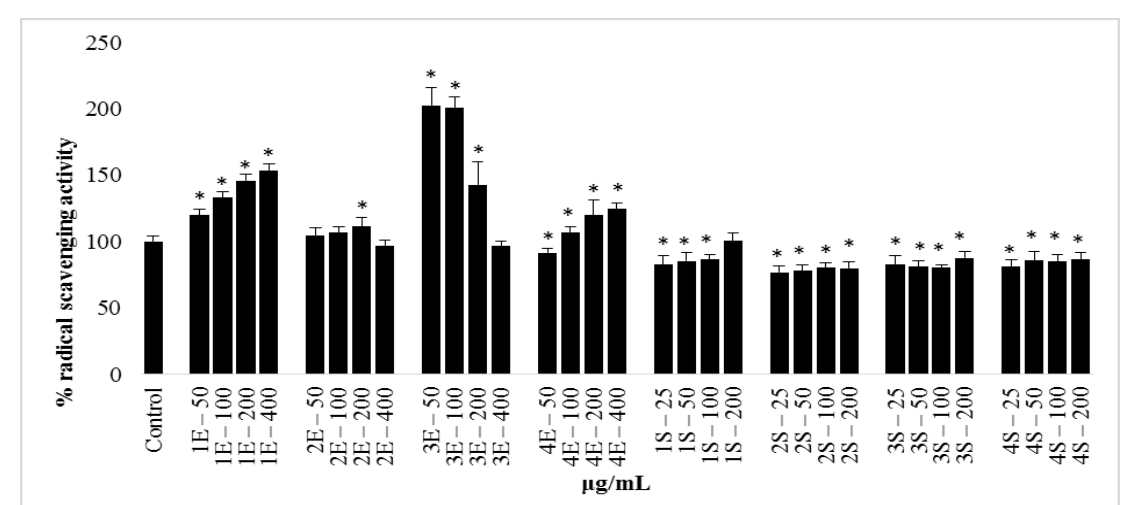

Figure 3. SO radical scavenging activities of the extracts and compounds

1E: Methanol extract, 2E: $\mathrm{H}_{2} \mathrm{O}$ subextract, 3E: EtOAc subextract, 4E: $\mathrm{CHCl}_{3}$ subextract, $1 \mathrm{~S}$ : Quercetin, $2 \mathrm{~S}$ : Daidzein-4'-O- $\beta$-glucoside, $3 \mathrm{~S}$ : Genistein, 4S: Daidzein.* significantly different from control $(\mathrm{p}<0.05)$. Results are expressed as mean \pm SD values of three observations.

Application of the NO method revealed the best property for chloroform subextract with an inhibition ratio of $310.69 \%$ at $400 \mu \mathrm{g} / \mathrm{mL}$ concentration and, among the compounds, daidzein was the most active one with an inhibition ratio of $168.59 \%$ at $50 \mu \mathrm{g} / \mathrm{mL}$ concentration (Figure 4). 


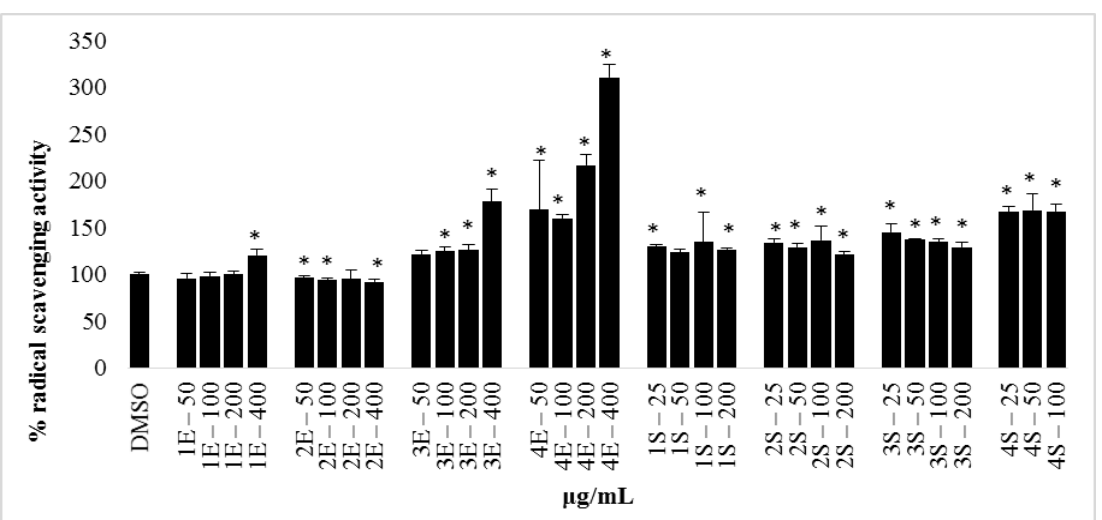

Figure 4. NO radical scavenging activities of the extracts and compounds

1E: Methanol extract, 2E: $\mathrm{H}_{2} \mathrm{O}$ subextract, 3E: EtOAc subextract, 4E: $\mathrm{CHCl}_{3}$ subextract, $1 \mathrm{~S}$ : Quercetin, $2 \mathrm{~S}$ : Daidzein-4'-O- $\beta$-glucoside, $3 \mathrm{~S}$ : Genistein, 4S: Daidzein.* significantly different from control $(\mathrm{p}<0.05)$. Results are expressed as mean \pm SD values of three observations.

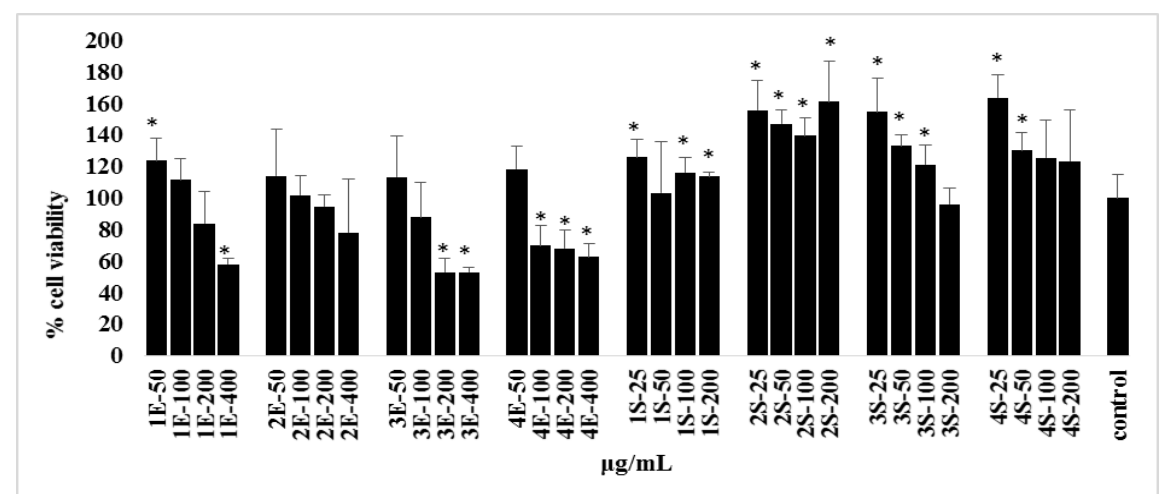

Figure 5. Cytotoxic effect of the extracts and compounds.

1E: Methanol extract, 2E: $\mathrm{H}_{2} \mathrm{O}$ subextract, 3E: EtOAc subextract, 4E: $\mathrm{CHCl}_{3}$ subextract, $1 \mathrm{~S}$ : Quercetin, $2 \mathrm{~S}$ : Daidzein-4'-O- $\beta$-glucoside, $3 \mathrm{~S}$ : Genistein, 4S: Daidzein.* significantly different from control $(\mathrm{p}<0.05)$. Results are expressed as mean \pm SD values of three observations.

Our findings revealed that extracts have higher cytotoxic effect when compared with the compounds which did not show any cytotoxic effect at tested concentrations (Figure. 5). The most active extract was ethyl acetate subextract that exhibited cytotoxic effect at $400 \mu \mathrm{g} / \mathrm{mL}$. However, the cytotoxic potential of the compounds and extracts were not distinctive. Besides, the cell viability did not drop till $50 \%$ at the concentration used.

As a conclusion, in our study, we investigated the radical scavenging and cytotoxic activity of the extracts and compounds obtained from T. trichocephalum. Our literature search displayed that no any biological activity studies on $T$. trichocephalum is available up to date. Additionally, daidzein, genistein, quercetin, and daidzein $4^{\prime}-O-\beta$-glucoside have been isolated for the first time from this species in our study.

In furtherance, the antioxidant capacity of the T. trichocephalum extracts presented herein can be attributed possibly to its flavonoid and isoflavonoid constituents. According to the results of our study, especially the isolated compounds can be considered as potential antioxidant agents. Further research on the isolated compounds in terms of therapeutic efficacy and toxicity seems to be useful.

\section{Acknowledgments}

This research was supported by the Scientific Research Foundation of the Karadeniz Technical University (Project number 1230).

\section{Supporting Information}

Supporting Information accompanies this paper on http://www.acgpubs.org/RNP 


\section{References}

[1] M. Zohary (1970). Trifolium L., In: Flora of Turkey and East Aegean Islands, ed: P.H. Davis, Edinburgh, Edinburgh University Press, Vol. 3, pp. 384-448.

[2] E. Sezik, E. Yesilada, M. Tabata, G. Honda, Y. Takaishi and T. Fujita, T (1997). Traditional medicine in Turkey 8. Folk medicine in East Anatolia; Erzurum, Erzincan, Agri, Kars, Igdir provinces, Econ Bot. 51, 195-211.

[3] T. Baytop (1999). Phytotherapy in Turkey- In the Past and Today, Nobel, İstanbul.

[4] T. Sabudak and N. Güler (2009). Trifolium L. - A review on its phytochemical and pharmacological profile, Phytother. Res. 23, 439-446.

[5] T. Baytop (2007). Dictionary of Plant Names in Turkish. Atatürk Culture, High Language and History Association, Ankara.

[6] G. Algan and N.B. Büyükkartal (1999). Apomictic development in tetraploid red clover (Trifolium pratense L.), Turk. J. Agric. For. 23, 519-525.

[7] G. Schultz and I. Böhrer (1971). Flavones of Trifolium pannonicum, Phytochemistry 10, 3315.

[8] A.M. Simonet, A. Stochmal, W. Oleszek and F.A. Macias (1999). Saponins and polar compounds from Trifolium resupinatum, Phytochemistry 51, 1065-1067.

[9] K.M. Mohamed, M. H. Mohamed, K. Ohtani, R. Kasai and K. Yamasaki (1999). Megastigmane glycosides from seeds of Trifolium alexandrinum, Phytochemistry 50, 859-862.

[10] A. A. Drenin, E.K. Botirov and E.V. Petrulyak (2008). Two new isoflavonoid monogalactosides from Trifolium pretense, Chem. Nat. Comp. 44, 24-27.

[11] J. Perez, A.M. Simonet, Ł. Pecioa, M. Kowalczyka, J.M. Calle and F.A. Macías (2015). Triterpenoid saponins from the aerial parts of Trifolium argutum Sol. and their phytotoxic evaluation, Phytochem. Lett. 13, 165-170.

[12] K.G. Shalashvili and E.P. Kemertelidze (1975). Flavonoids from Trifolium trichocephalum, Chem. Nat. Compd. 5, 653

[13] A. Caligiani, G. Palla, A. Maietti, M. Cirlini and V. Brandolini (2010). ${ }^{1}$ H NMR fingerprinting of soybean extracts, with emphasis on identification and quantification of isoflavones, Nutrients 2, 280-289.

[14] K. Nara, K. Nihei, Y. Ogasawara, H. Koga and Y. Kato (2011). Novel isoflavone diglycoside in groundnut (Apios americana Medik), Food Chem. 124, 703-710.

[15] Z. Güvenalp and Ö. Demirezer (2005). Flavonol glycosides from Asperula arvensis L, Turk. J. Chem. 29, 163-169.

[16] P.K. Agrawal (1989). Carbon-13 NMR of Flavonoids. Elsevier Science Publishers, Amsterdam.

[17] N. Martins, L. Barros and C.F.R. Ferreira (2016). In vivo antioxidant activity of phenolic compounds facts and gaps, trends, Food Sci. Technol. 48, 1-12.

[18] Q. Guo, G. Rimbach, H. Moini, S. Weber and L. Packer (2002). ESR and cell culture studies on free radical-scavenging and antioxidant activities of isoflavonoids, Toxicology. 179, 1-2.

[19] B. Sreedhar, T.V. Reddy, C.N. Raju and G.V.S. Reddy (2016). Design, synthesis, characterization and bioassay of novel carboxamide derivatives of celecoxib, Org. Commun. 9, 54-64

[20] E. Kunchandy and M.N.A. Rao (1990). Oxygen radical scavenging activity of curcumin, Int. J. Pharmacol. 58, 237-240.

[21] D. Şöhretoğlu, S. Sabuncuoğlu and U.S. Harput (2012). Evaluation of antioxidative protective effect against $\mathrm{H}_{2} \mathrm{O}_{2}$ induced cytotoxicity and cytotoxic activities of three different Quercus species, Food Chem Toxicol. 50, 141-146.

[22] N.B. Reddy, C.S. Sundar, S.H. Jayaprakash, G. Mohan, P.V. Reddy and C.S. Reddy (2015). Synthesis and antioxidant activity of dioxazaphosphinin-2-ones, Org. Commun. 8, 17-23.

[23] N. Ohguro, M. Fukuda, T. Sasabe and Y. Tano (1999). Concentration dependent effects of hydrogen peroxide on lens epithelial cells, Br. J. Ophthalmol. 83, 1064-1068.

[24] G. Shui, Y.M. Bao and J. Bo (2006). Protective effect of protocatechuic acid from Alpinia oxyphylla on hydrogen peroxide-induced oxidative PC12 cell death, Eur. J. Pharmacol. 538, 73-79.

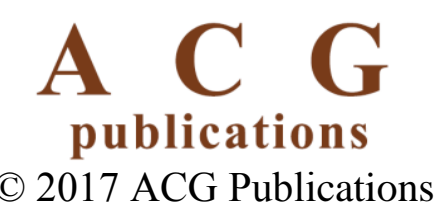

